\title{
Teaching information sources and business informa- tion sources and services at the Department of Li- brary and Information Sciences at György Bessenyei Teachers' Training College
}

\author{
Ágnes Szerafin-Szabolcsi and Anikó Tanyi-Kocsis \\ György Bessenyei Teachers' Training College, Sóstói ut. 31/B, Nyíregyháza, H-4400 Hungary
}

\begin{abstract}
Since the 1980s there have been several changes in the environment of libraries in Hungary, and there are new demands on higher education institutions for education and training in Library and Information Science. With funding from a TEMPUS JEP, an up-to-date library-laboratory was set up György Bessenyei Teachers' Training College, Nyíregyháza in the 1994-95 academic year. Now not only hard copy information sources but all kind of formats in which information may be supplied can be used for teaching new courses in Information Sources and Business Information Sources and Services.
\end{abstract}

\section{Introduction}

With the change of regime in Hungary, a lot of factors influenced the library environment and library system. Those institutions training librarians had to consider the following aspects when planning their training:

- Changes in the Hungarian society (political situation, economy, industry, etc.).

- Information Technology in the Hungarian libraries.

- New formats (electronic products, e.g., online, CD-ROM).

- Internet access.

- The role of libraries has changed.

- New services (e.g., Business Services, etc.).

- New skills are needed.

Historians consider 1990 as a significant year for political and economic changes in Hungary as it was marked by a lot of important events, such as the introduction of a multi-party system and market economy, and leaving the association of former socialist countries. One of the main results and characteristic features of the economic 
changes is that small and medium size companies have been established, creating a need for new types of information. Changing to a market economy would, indeed, have been much more difficult without applying the new Information Technology.

The development of telecommunication and information networks has also accelerated. By the first half of the 1990s, electronic information exchange between research centres and the information and higher education institutions became possible. A new national data network, which is based on X.25, was also developed, and access to the services of distant computers and databases became practicable.

By the beginning of the 1990s, new document formats appeared in library collections. The role of libraries began to be considered differently: as the technological basis of their collections, and their storing and searching systems, assumed a greater importance in the dissemination of information. The development of libraries suggested introducing electronic sources, but at the same time they also had to ensure the continuation of services based on traditional sources. Both acquiring and using electronic information materials proved a great challenge.

This manifold and deep change has compelled the Hungarian teaching institutions to renew their curriculum, teaching and training methods, as the future's librarians need new skills.

\section{The education of librarians in Nyíregyháza}

In György Bessenyei Teachers' Training College, Nyíregyháza in eastern Hungary, education for librarianship was established in 1976. The curriculum is based on two majors. Students can choose Library and Information Science as a major with foreign languages (English, German, Italian, French), Hungarian language, History, Mathematics, Biology, Chemistry, or Informatics. In 1996-97, all 200 full-time students are enrolled in Library and Information Science. After the 4-year programme, they become teachers in primary schools where they can work as school librarians, but they can, and do, also successfully apply for positions in public of special libraries.

In the first part of the curriculum for librarianship, students take several basic subjects such as Introduction to Library and Information Science, Desktop Publishing Communication, History of Culture, Cultural Sociology, Bibliographic Description, Information Retrieval Languages, Library Systems, Foreign language, Classification, Database Management.

\section{TEMPUS Joint European Project}

At the beginning of 1990, the Department started to revise the curriculum. At the same time the Hungarian library environment was developing rapidly with the help of Information Technology. On practical places, mainly in special libraries, students can use the latest Information Technology and all kinds of formats, online access, CDROM and the Internet. On the other hand, the College (along with all other higher 
education institutions in Hungary) faced very serious financial problems. The College welcomed the possibility of external support from the European Commission through a TEMPUS Joint European Project, which has also supported similar developments in Berzsenyi Daniel Teachers' Training College in Szombathely in western Hungary. This commenced in 1994 and concludes in 1997. The partners from the European Union who have taken part in the project are Danmarks Biblioteksskole, Copenhagen; the School of Information and Media, The Robert Gordon University, Aberdeen; De Montfort University Library, Leicester; and Fachhochschule für Bibliotheks- und Informationswesen, Stuttgart. The project had 3 principal aims:

- Development of infrastructure.

- Development of curricula.

- Staff and student mobility for familiarisation with advanced information services and teaching.

The current curriculum was introduced in the 1993/94 academic year, but in 1996/97 a radical reform was introduced, based on developments in Information Technology. With the help of the TEMPUS funds, a computer laboratory was set up in the 1994/95 academic year with online and Internet access, and DIALOG extended to the partners the facilities of the Classroom Instruction Programme. Information Technology began to be integrated into the programme. Staff mobility funds provided the opportunities to become familiar with the way in which institutions in western Europe are using and teaching Information Technology. As a part of this work and as a response to the new demands of the professional community in Hungary, the curriculum was revised. After the first part of the curriculum, Information Sources is now taught as a 3-semester subject with a new 3-semester subject Business Information Sources.

\section{Content of the new courses}

Information Sources for full-time students commences in the 5th semester, and comprises a 1-hour lecture plus a 2-hour seminar each week, giving a total of 45 hours instruction during the semester.

Information Sources 1 covers lexicons, encyclopaedias, dictionaries, data-books, statistical sources, directories and bibliographies. Subject elements include user needs, the reference interview, search strategy, case studies in libraries, service design and organisation. Information Sources 2 covers special information sources, e.g., standards, patents, scientific research reports, dissertations, special bibliographies including indexing and abstracting services, user needs, search strategies, bibliography compilation. Information Sources 3 covers online information retrieval, CD-ROM technology, Internet, based on information enquiry.

Business Information Sources I follows in the 6th semester. Based on the very basic knowledge of Information Sources 1, subject elements include economic and financial elements and use of a foreign language. At this time the students are able to 
use all kinds of information sources and search strategies individually. In this semester students are given some different issues and definitions of the term Business Information, characteristic features, types of Business Information (facts, legal rules, market analyses), basic knowledge of enterprise (features and types), one-man and common private enterprises, which are very common in Hungary. Students also learn about starting an enterprise and making a business plan in a 2-hour seminar each week. Business Information Sources II covers traditional and electronic sources of economic and financial information according to the types of Business Information, e.g., sources of market information, like statistical data collections, market research abstracts, market research guides and periodicals. It introduces foreign databases through the DIALOG host (examining, e.g., DIALOG Business Connection, Standard and Poors, Thomas Register Online, etc.), and relevant CD-ROMs and Internet Web sites in a 2-hour seminar each week. In Business Information Sciences III, the main topic of the weekly 2-hour seminar is the organisation, development and introduction of a Business Information Service, covering the marketing plan, questions of financing, the role of communication, main elements and possible variants of public relations.

\section{Teaching methods}

The authors graduated from the College with the same majors (Hungarian Language and Literature with Library and Information Science) in 1982 and 1990. At that time they were expected to memorise lists of titles and their contents in studying "reference work". In contrast, nowadays various teaching methods are used. In the lectures new information has to be given verbally because there are few, if any, modern textbooks for studying these subjects. Teaching is based on the "type of material" and the "case study" approach. Students are introduced to a variety of sources in hard copy, online and CD-ROM formats. In the seminars, students work in workshops or individually. After analysing the sources, they are required to answer real enquiries based on case studies. They are expected to know how to synthesise different works on the same topic.

The most important role of the seminars is to make the students able to evaluate, analyse the obtained knowledge and to judge the facts correctly. Debates after discussing the sources are common, and on these occasions students have an opportunity to resolve any questions.

In the final semester of Business Information Sources and Services, different roleplays are very popular among students. Typical situations are selected for demonstrating efficient marketing work. Presentations about companies and visiting them are also popular because they give an opportunity to meet other members of the information industry, and are expected to become more frequent in the future. 
Assessment of the students is based on exercises set by the teachers, individual students' assignments, and presentations in the seminars.

\section{Conclusions}

In 1996/97, the development of the curriculum will be completed, but other work will continue. The development of Information Technology is so explosive that we have to be flexible enough to adapt to international, national and local needs and requirements. Although the TEMPUS project is coming to an end, the Department will continue to make an effort to develop a modern and up-to-date curriculum by using, and integrating Information Technology. To get a clearer picture about local needs and demands, we propose to make a survey in the near future among the library users and businessmen in the region. With the help of the survey's evaluation, further revisions will be made to the courses. We have to give a wider range of knowledge and skills to our students than before, and we have to give them competitive advantages in the employment market.

\section{References}

[1] Workshop on Education and Training of Information Specialists in Eastern Europe. Education for Information 13 (1995) 53-56.

[2] M.C. Head and R. Marcella. Teaching "reference work" in Aberdeen: a personal perspective. Education for Information 13 (1995) 67-71.

[3] N.O. Pors. Curriculum development and student's perceptions. Proceedings of the 1st BritishNordic Conference on Library and Information Studies, 22-24 May 1995. Copenhagen. Eds M. Beaulieu and N.O. Pors. Copenhagen: Danmarks Biblioteksskole. pp. 7-15.

[4] P. Szántó and H. Huszár. Business information in Hungary. FID News Bulletin 6 (1993) 127-129.

[5] H. Butcher. Business Information Curricula: an employer's list of essential skills and knowledge. Education for Information 7 (1989) 335-341. 